\title{
Physicochemical, Microbial and Sensory Characteristics of Yoghurt Processed by Adding Various Formulations of Gum Arabic and Guar Gum
}

\author{
Zakaria A. Salih ${ }^{1,2}$, Azhari Siddeeg ${ }^{2}$, Ammar Al-Farga $^{3^{*}}$, Rasha M. A. Mousa ${ }^{3,4}$ \\ S. A. Husam ${ }^{2}$ and A. S. Al Zubair \\ ${ }^{1}$ Research and Training Station, King Faisal University, Saudi Arabia. \\ ${ }^{2}$ Department of Food Engineering and Technology, Faculty of Engineering and Technology, \\ University of Gezira, Wad-Medani, Sudan. \\ ${ }^{3}$ Department of Biochemistry, College of Sciences, University of Jeddah, Jeddah, Saudi Arabia. \\ ${ }^{4}$ Home Economic Department, Faculty of Specific Education, Assiut University, 71516 Assiut, Egypt.
}

\section{Authors' contributions}

This work was carried out in collaboration among all authors. Author ZAS have made substantial contributions to conception and design. Author AS have made acquisition of data. Author AAF have made analysis and interpretation of data. Author RMAM have been involved in drafting the manuscript. Author SAH revised it critically for important intellectual content. Author ASAZ have given final approval of the version to be published.

Article Information

DOI: $10.9734 / A R R B / 2020 / v 35 i 1130297$ Editor(s):

(1) Dr. Gonzalo Emiliano Aranda Abreu, Veracruzana University, Mexico.

(1) Agnes Sri Harti, Universitas Kusuma Husada, Indonesia. (2) Loveleen Kaur Sarao, Punjab Agricultural University, India. Complete Peer review History: http://www.sdiarticle4.com/review-history/62151

\begin{abstract}
Yoghurt is one of the most popular fermented dairy products widely consumed all over the world. The present study aimed to evaluate the physicochemical, microbial and sensory characteristics of yoghurt produced by added various levels of Gum Arabic and Guar gum (stabilizers). Physicochemical characteristics, microbial characteristics and sensory evaluation of processed yoghurt samples were conducted under laboratory conditions by standard methods. The results showed that yoghurt produced by the addition of Gum Arabic at concentrations $(0.2,0.35$, and $0.5 \%$ ) had less serum separation $(1.6,1.4$, and $3.3 \mathrm{ml} / \mathrm{l})$ after 9 days compared with that produced by adding Guar gum (4.5., 3.1., $0.0 \mathrm{ml} / \mathrm{lit}$ ), respectively, and their mixture (4.3., 6.1. and $3.5 \mathrm{ml} / \mathrm{l})$. Results reported significant differences in $\mathrm{pH}$ values $(4.9,4.5$, and 3.9$)$ during storage $(0,3$, and 9
\end{abstract}


days), respectively for all types of stabilizers added. The results illustrated significant differences in total solid $(7-8 \%)$ at different concentrations during the storage period. The study showed no significant difference in stabilizers (Gum Arabic and Guar Gum). The effect of storage on microbial characteristics was determined and the results showed that all microbial characteristics except coliform bacteria showed a significant decrease in the supplemented yoghurt samples compared with those of control yoghurt, while no effect with stabilizer concentration on microbial characteristics. Sensory characteristics (texture, color, and overall acceptability) were significantly improved, while the flavor was not affected with type and concentrations of stabilizers, but affected with storage period. Yoghurt processed with the addition of Gum Arabic had best quality characteristics than yoghurt made with addition Guar gum and a mixture of them. The study recommended doing more researches in rheological, microbial, and sensory characteristics to improve the quality of yoghurt.

Keywords: Yoghurt; Arabic gum; guar gum; physicochemical properties; microbial; properties; sensory properties.

\section{INTRODUCTION}

Yoghurt is one of the most popular fermented milk products in the world and contains beneficial viable micro-organisms that compete with pathogenic bacteria for nutrients and space [1-2]. Yoghurt or the yogurt-manufacturing technique is an ancient one, dating back to thousands of years. Symbiotic thermophilic starter cultures, namely Lactobacillus delbrueckii subsp. bulgaricus and Streptococcus salivarius subsp. thermophilus, were the principal starter strains used in the yogurt preparation [3]. Yogurt is often included in the lists of healthy foods due to its high nutritive value. It is an excellent source of proteins, vitamins, and minerals. Yogurt can be prepared specifically to meet particular nutritional requirements of people whose normal processes of metabolism are altered or those who want a particular effect by controlled intake of foods or certain nutrients [4]. The main ingredient in yoghurt is milk, the type of milk depends on the type of yoghurt also stabilizers used in yoghurt to improve the body and texture by increasing firmness, preventing separation of the whey, and helping to keep the fruit uniformly mixed in the yoghurt. The texture is one of the main characters that define the quality of yogurt. The most frequent defects related to yogurt texture, which may lead to consumer rejection, are apparent viscosity variations and the occurrence of the physical attributes of yogurts, including the lack of visual whey separation and perceived viscosity, are crucial aspects of the quality and overall sensory consumer acceptance of yogurts [5]. Syneresis can be reduced by adding stabilizers that interact with the casein network. The viscosity of yogurt is affected by homogenization, $\mathrm{pH}$, processing parameters (stirred or set yoghurt), and heat treatment. A primary stabilizer, such as carboxymethyl cellulose (CMC), Locust Bean Gum (LBG), Alginate, or Guar, gum, can be used as a thickener in conjunction with a secondary stabilizer, such as Carrageenan to reduce syneresis [6]. In the food industry, guar gum is used as a thickening and stabilizing agent in a wide variety of food [7]. It is demonstrated that while Gum Arabic adsorbs strongly and effectively onto the oil droplets via its proteinaceous moieties, guar gum and locust bean gum adsorb weakly and, for the most part, only "precipitate" on the oil surface, and form birefringent layers of the polymer oriented with its hydrophobic mannose backbone facing the oil [8]. The gums could control the rheology and texture throughout the stabilization of emulsions, suspensions, foams, and starch gelatinization [9]. Some studies have been conducted on the effect of some gums on the physicochemical properties of ice cream [10], and various studies have evaluated the effect of guar gum on the physicochemical, sensory, and flow behavior characteristics of yoghurt [11,12-13]. They found that the addition of guar gum increased the viscosity and sensory properties of yoghurt. This study aimed to investigate the effect of supplementation of yoghurt with Gum Arabic and Guar gum on some physicochemical, microbial, and sensory characteristics of Yoghurt.

\section{MATERIALS AND METHODS}

\subsection{Materials}

Skim milk powder $(50 \mathrm{Kg})$, butter oil (4 Kg), and starter culture (1:1 combination of Streptococcus thermophilus and Lactobacillus bulgaricus were obtained from Best Factory for Dairy and Juices 
products (Khartoum). Guar and Gum Arabic were supplied by Khartoum Gum Arabic Company Ltd.

\subsection{Methods}

\subsubsection{Yoghurt production}

Yoghurt was manufactured according to the method described by [14]. Yoghurt made from skimmed milk powder (10.5\%) solids-non-fat (S.N.F) and butter oil (1.5\%) with the addition of starter culture at the rate of $(3 \%)$. Guar gum, Gum Arabic, and a mixture of the two stabilizers at ratio $1: 1$ was added to reconstituted milk at $0.2 \%, 0.35 \%$, and $0.5 \%(\mathrm{w} / \mathrm{v})$. Skim milk powder, stabilizers, and butter oil were mixed and added to warm water at $45^{\circ} \mathrm{C}$ and stirred for half an hour by an emulsifier to breakdown fat particles into smaller ones as a pre-step for homogenization. The mixture was homogenized for 10 minutes at 1430 revolution per minute (rpm) using a homogenizer (Ultrasonic). Then the mixture was pasteurized at $85^{\circ} \mathrm{C}$ for 30 minutes using a water bath. After cooling at $45^{\circ} \mathrm{C}$ the starter culture was added at the ratio of $3 \%(\mathrm{v} / \mathrm{v})$, then the mixture was packed in labeled disinfected cups, covered by aluminum foil, and incubated at $45^{\circ} \mathrm{C}$ for 4 hours. After 4 fours, yoghurt was removed from the incubator and stored in a cooler at $10^{\circ} \mathrm{C}$ for 9 days and analyzed at intervals of 3 and 9 days.

\subsubsection{Physicochemical analysis}

The fat content was determined by the Gerber method according to [15] as follows: 9.5 milliner's $851 \mathrm{f}$ sulfuric acid (density $1.815 \mathrm{mg} / \mathrm{ml}$ at $20^{\circ} \mathrm{C}$ and distilled water at $3 \mathrm{ml}$ of amyl alcohol (density $0.814-0.816 \mathrm{mg}$ malt $20^{\circ} \mathrm{C}$ ) and distilled water at $20^{\circ} \mathrm{C}$, and (rpm) for 15 minutes, and the tubes were then transferred to a bath at $65^{\circ} \mathrm{C}$. For 3 minutes. The fat percent was then read out directly from the fat column. The Total Soluble Solids (TSS) were determined as per the method described by [16] using a Digital-BenchRefractometer. Before use, the instrument was cleaned and adjusted to zero at $20^{\circ} \mathrm{C}$ using distilled water. An appropriate quantity of samples of each product prepared was placed on the prism-plate of the refractometer with the help of a glass rod and folding back the cover. For each sample, the instrument was calibrated using distilled water. The reading that appeared on the screen was directly recorded as total soluble solids as Brix. Serum was determined by putting $25 \mathrm{ml}$ of yoghurt sample on filter paper. After 2 hours the volume was collected in $\mathrm{ml}$ per
$25 \mathrm{ml}$ of initial yoghurt sample. $\mathrm{pH}$ values were measured using an electric $\mathrm{pH}$ meter model 501 according to [16].

\subsubsection{Microbiology tests}

For the accomplishment of the microbiological analysis, serial of dilutions was prepared, for this; the samples were homogenized with peptone water. 10 grams of each sample was weighed and added to a conical flask containing $90 \mathrm{ml}$ of $0.1 \%$ peptone water and shaking well for $30 \mathrm{~min}$ using a shaker (15 rpm). This dilution is referred to as a mother solution (dilution $10^{-1}$ ). One $\mathrm{ml}$ of mother solution was pipette with a sterile pipette into $9 \mathrm{ml}$ sterile peptone water (dilution $10^{-2}$ ) and serial decimal dilution up to $10^{-5}$ ). The total viable count per $\mathrm{ml}$ of sample was obtained by pourplating suitable in triplicates on plate Count Ager (Oxoid) following the method of APHA, (1967). Incubation was accomplished at $37 \mathrm{C}^{\circ}$ for 48 hours. Lactic acid bacteria count was determined according to the method described by Kiss, (1984), using MRS media, after anaerobic incubation at $37^{\circ} \mathrm{C}$ for 48 hours the different types of colonies were counted. Plates containing between 30 and 300 colonies were counted a colony-forming unit (C.F.U) per $\mathrm{ml}$ of the sample. Yeast and mold were enumerated according to [17] using potato Dextrose Agar (PDA). The plates were incubated at $25 \mathrm{C}^{\circ}$ for $3-5$ days, plates containing between $30-300$ colonies were counted as colony forming units (C.F.U/ml). Coliform bacterial count was determined according to [17] using Mac Conkey broth. The tubes were incubated at $37^{\circ} \mathrm{C}$ for 48 hours. Positive tubes gave gas in Durham tubes. Then the positive tubes were subcultured into an EC broth medium and then incubated at $44^{\circ} \mathrm{C}$ for 24 hours to determine the Coliform bacteria, the tube showing any amount of gas production were considered positive. Salmonella count was determined according to [18]. $100 \mathrm{ml}$ of samples was incubated at $37^{\circ} \mathrm{C}$ for 24 hours. Then $10 \mathrm{ml}$ were drawn aseptically and added to $100 \mathrm{ml}$ Selenite Broth. The broth was incubated at $37^{\circ} \mathrm{C}$ for 24 hours then with a loopful streaking was done on dried Bismuth Sulphite agar plates. The plates were then incubated at $37^{\circ} \mathrm{C}$ for 72 hours. Black metallic sheen discrete colonies indicated the presence of Salmonella. A confirmatory test was carried out by taking a discrete black. Staphylococcus aureus counts were investigated by the procedure of [19]. 0.1 was plated onto Baird Parker Agar media and inoculums were distributed evenly using a sterile glass rod. The plates were then incubated at $37^{\circ} \mathrm{C}$ for $24-48$ 
hours and the counts were presented as colonyforming units per gram (cfu/g).

\subsubsection{Sensory evaluation}

All kinds of yoghurt were displayed for sensory evaluation using 15 panelists on the second day of storage. The panelists were asked to evaluate samples by appearance, flavor, texture, overall ranking, and using 5 points, top mark for 5 , and less marked for 1 .

\subsubsection{Statistical analysis}

Statistical analysis was done using Statistical Package for Social Studies Software SPSS. Complete Randomized Design was used to estimate the chemical, microbiological, and sensory characteristics of the yoghurt.

\section{RESULTS AND DISCUSSION}

\subsection{Physicochemical Properties Yoghurt Produced by Gum Arabic}

The result of the physicochemical of yoghurt products using Gum Arabic as a Stabilizer are presented in Table 1. The total solid content of yoghurt produced by using $0.2 \%$ concentrations of Gum Arabic as a stabilizer at 0,3,9 days were $8.59,8.11,7.99 \%$, respectively. and $8.61,8.09,7.99$ at $0.35 \%$ Gum Arabic, also $8.62,8.11,7.99$ at concentration $0.5 \%$. The total solid content of yoghurt samples was affected significantly by the storage period. The highest total solid $(8.62$, ) was found at day zero, while the lowest one $(7.99 \%)$ on day 9 . This result is in agreement with those reported by [20], who found that the addition of Prunus cerasus gum exudates (PCGE) at evaluated concentrations had an increasing effect on total solids contents of yogurt. Also, similar values of total solids were reported by [21], who found the total solids were continued increasing with an increased amount of Gum powder. The $\mathrm{pH}$ values of yoghurt produced by the addition of $2 \%$ Gum Arabic at 0 , 3 , and 9 days were 4.5, 4.1, and 3.9, respectively. Besides, $\mathrm{pH}$ values of yoghurt supplemented with $0.35 \%$ and $0.5 \%$ Gum Arabic were $4.1,4.1,3.9$ and $4.2,3.9,3.9$, respectively. The $\mathrm{pH}$ values of the yoghurt samples showed were significantly increased from 4.5 at day zero to 3.9 on day 9 . The apparent decline in $\mathrm{pH}$ values could be attributed to the continuation of fermentation by lactic acid bacteria. These results were in close agreement with those obtained by [22]., who reported that the $\mathrm{pH}$ values there are significant differences in $\mathrm{pH}$ values of Yoghurt and fermented milk (Robe) during the storage period and stabilizer concentration. Moreover, [23-24], reported a reduction in $\mathrm{pH}$ values yoghurt by the addition of chitosan stabilizer during 20-day storage. Table 1 presented the serum separation values of yoghurt produced by addition of $0.2 \%$ Gum Arabic at $0,3,9$ days of storage are $0.0,0.0,1.1$ $\mathrm{ml}$, respectively, and $0.5,1.3,1.5 \mathrm{ml}$ at $0.35 \%$ Gum Arabic concentration also 0.6,1.2,1.5 ml at $0.5 \%$ concentration of stabilizer. The results indicated that there were highly significant differences in the serum separation values due to all the treatments. This result was near than results obtained by [21-25] who reported that the serum separation values were increased with increasing storage time and decreased with an increasing amount of gums. [26,27-28], have reported that the utilization of thickener can be utilized as an appropriate method for controlling syneresis of fermented milk. Results in Table 1 illustrates the fat content of yoghurt produced by addition of $0.2 \%$ and $0.35 \%$ Gum Arabic at $0,3,9$ days were $0.95,0.56,0.39 \%$, respectively, and $0.95,0.49,0.29 \%$, respectively and $1.03,0.59$, 0.38 at $0.5 \%$ concentration of stabilizer. The fat content of the yoghurt produced by the addition of different stabilizers was affected significantly by the storage period. These results were less than the results obtained by [21]. Who reported that the fat content results are $1.80,1.87,2,00$ at $0,5,10$ days, respectively. Also, [22] found that the fat content of fermented milk (Robe) formulated by Gum Arabic decreased during refrigerated storage for 7 and 15 days. The protein of yoghurt produced by addition of $0.2 \%$ Gum Arabic at 0, 3,9 days are 2.89, 2.41, 2.10\%, respectively, and at $0.35 \%$ Gum Arabic were $2.90,2.33,2.14 \%$, respectively and at $0.5 \%$ Gum Arabic concentration were $2.78,2.39,2.01 \%$, respectively. The protein content of the yoghurt production was affected significantly by the storage period. The highest protein content $(2.89 \%)$ was observed at zero-days, while the lowest one $(2.01 \%)$ on day 9 . These results were similar to those obtained by [21], who reported significant differences in protein contents during the storage period which were $4.27,5.48,5,84$ at $0,5,10$ days in Yoghurt supplemented with 0/5\% Gum Arabic, respectively. 
Table 1. Physicochemical of yoghurt product using Gum Arabic as a stabilizer (Means)

\begin{tabular}{|c|c|c|c|c|c|c|c|}
\hline Stabilizer & $\begin{array}{l}\text { Stabilizer } \\
\text { Concentration \% }\end{array}$ & $\begin{array}{l}\text { Storage Time } \\
\text { Days }\end{array}$ & $\begin{array}{l}\text { Total Solid } \\
\%\end{array}$ & $\mathrm{pH}$ & $\begin{array}{l}\text { Serum } \\
\text { separation }(\mathrm{ml})\end{array}$ & Fat content \% & Protein \% \\
\hline \multirow[t]{3}{*}{ GA } & 0.2 & 0 & $8.59 \pm 0.09^{a}$ & $4.5 \pm 0.07^{a}$ & 0.0 & $0.95 \pm 0.09^{b}$ & $2.89 \pm 0.03^{\mathrm{a}}$ \\
\hline & & 3 & $8.11 \pm 0.10^{a}$ & $4.1 \pm 0.30^{b}$ & 0.0 & $0.56 \pm 0.70^{c}$ & $2.41 \pm 0.11^{b}$ \\
\hline & & 9 & $7.99 \pm 0.90^{\mathrm{b}}$ & $3.9 \pm 0.40^{\mathrm{c}}$ & $1.1 \pm 0.10^{c}$ & $0.39 \pm 0.05^{c}$ & $2.10 \pm 0.07^{c}$ \\
\hline \multirow[t]{3}{*}{ GA } & 0.35 & 0 & $8.61 \pm 0.08^{a}$ & $4.1 \pm 0.10^{b}$ & $0.5 \pm 0.70^{d}$ & $0.95 \pm 0.02^{b}$ & $2.90 \pm 0.90^{\mathrm{a}}$ \\
\hline & & 3 & $8.09 \pm 0.11^{a}$ & $4.1 \pm 0.10^{b}$ & $1.3 \pm 0.40^{b}$ & $0.49 \pm 0.50^{c}$ & $2.33 \pm 0.10^{b}$ \\
\hline & & 9 & $7.99 \pm 0.06^{b}$ & $3.9 \pm 0.70^{c}$ & $1.5 \pm 0.20^{a}$ & $0.29 \pm 0.10^{d}$ & $2.14 \pm 0.04^{c}$ \\
\hline \multirow[t]{3}{*}{ GA } & 0.5 & 0 & $8.62 \pm 0.40 a$ & $4.2 \pm 0.60^{\mathrm{b}}$ & $0.6 \pm 0.01^{d}$ & $1.03 \pm 0.03^{\mathrm{a}}$ & $2.78 \pm 0.40^{\mathrm{a}}$ \\
\hline & & 3 & $8.11 \pm 0.30^{\mathrm{a}}$ & $3.9 \pm 0.10^{c}$ & $1.2 \pm 0.08^{b}$ & $0.59 \pm 0.02^{c}$ & $2.39 \pm 0.20^{\mathrm{b}}$ \\
\hline & & 9 & $7.99 \pm 0.20^{\mathrm{b}}$ & $3.9 \pm 0.30^{c}$ & $1.5 \pm 0.09^{\mathrm{a}}$ & $0.38 \pm 0.10^{c}$ & $2.01 \pm 0.22^{\mathrm{c}}$ \\
\hline
\end{tabular}

GA: Gum Arabic. Similar superscript letters in the same column mean there is no significant difference ( $P \leq 0.05)$ 


\subsection{Physicochemical Properties Yoghurt Produced by Guar Gum}

The result of total solids, $\mathrm{pH}$, serum separation, fat content, and protein of yoghurt during $0,3,9$ days at different concentrations of the stabilizer are shown in Table 2. The total solid content of yoghurt produced by the addition of $2 \%$ Guar Gum at 0,3 , and 9 days were $8.50,8.08,7.80$, respectively. Also, the total solid content of yoghurt supplemented with $0.35 \%$ and $0.5 \%$ Guar Gum at 0,3 and 9 days were 8.55, 8.01, 7.88 , and $8.61,8.10,8$., respectively. There are significant differences between the results of total solid during the storage period, on the other hand, the concentration of stabilizer does not affect in total solid during the storage period. These results agreed with that reported by [29], who found total solid at different storage periods are $8.46,8.17$, and 7.92 at $0,3,10$ days, respectively. $\mathrm{pH}$ values of yoghurt produced by the addition of $0.2 \%$ Guar Gum at $0,3,9$ days were $4.1,3.9,3.5$, respectively, and at $0.35 \%$ Guar Gum were 3.5, 4.1,3.9, respectively and at 0.5\% Guar Gum concentration were 3.6, 3.4, 3., respectively. There are significant differences between results during the storage period and stabilizer concentration. The results are not far from those reported by [30], who reported that the $\mathrm{pH}$ values are less than 4.0. Also, Table 2 presented the serum separation values of yoghurt produced by the addition of Guar Gum $0.2 \%$ at $0,3,9$ days were 4.0., 4.1., 4.5., respectively, and at $0.35 \%$ Guar Gum were 2.0., 3.0., 3.1., respectively and at $0.5 \%$ Guar Gum concentration were $0,0,0$., respectively. There are significant differences between results during the storage period and stabilizer concentration. The serum separation was significantly affected by the addition of different levels of Guar Gum. This result is in agreement with those reported by [20], who found the addition of Prunus cerasus gum exudates (PCGE) had a significant effect on syneresis. Table 2 shows the fat content of yoghurt produced by addition of Guar Gum $0.2 \%$ at $0,3,9$ days were $0.99,0.51,0.37$, respectively, and at $0.35 \%$ Guar Gum were 0.98, 0.52, 0.31., respectively and at $0.5 \%$ Guar Gum concentration were $0.99,0.56,0.37$, respectively. The fat content yoghurt was no significant affected by the levels of Guar Gum. Fat contents determined in the present study were relatively similar to those reported by [21], who reported that the fat content yogurt produced by adding different levels of Gum statistically was no significant difference between all samples during the storage period. The protein content of yoghurt produced by the addition of Guar Gum $0.2 \%$ at $0,3,9$ days are $2.80,2.48,2.12$ (Table 2), respectively, and at $0.35 \%$ Guar Gum were 2.82, $2.30,2.19$., respectively and at $0.5 \%$ Guar Gum concentration were $2.75,2.32,2.05$, respectively. The protein content of yogurt produced by the addition of different levels of Guar Gum statistically was significantly different between all samples during the storage period.

\subsection{Physicochemical Properties of Yoghurt Produced by Adding Mixture of Gum Arabic and Guar Gum (1:1)}

The result of total solids, $\mathrm{pH}$, serum separation, fat content, and protein of yoghurt are during 0 , 3,9 days of storage at different concentrations of the stabilizer are shown in Table 3 showed the value of total solid of yoghurt produced by using $0.2 \%$ concentrations of Gums mixture as a stabilizer at $0,3,9$ days are $8.58,8.08,7.94 \%$, respectively, and at $0.35 \%$ and $0.5 \%$ Gums mixture concentration $0,3,9$ days are $8.57,8.04$, $7.95 \%$ and $8.61,8.12,7.92 \%$, respectively. There are significant differences between the results of the total solid during the storage period. Also, in this table show the $\mathrm{pH}$ values of yoghurt produced by the addition of Gums mixture as a stabilizer in $0.2 \%$ concentration at $0,3,9$ days are $4.1,4.2,3.7$, respectively, and $4.5,4.3,4.0$ in $0.35 \%$ Gums mixture concentration, and $4.2,4.1$, 4.0 in $0.5 \%$ concentration of stabilizer. There are significant differences between results during the storage period. The Table 3 presented the serum separation values of yoghurt produced by the addition of a mixture of Gums in concentrate $0.2 \%$ at $0,3,9$ days are $3.5,3.6 ., 4.3 \mathrm{ml}$, respectively, and at $0.35 \%$ of the mixture of Gums were $5.8,6.6,6.1 \mathrm{ml}$., respectively and at $0.5 \%$ of the mixture of Gums, concentration was $3.5,1.9,3.5 \mathrm{ml}$, respectively. There are significant differences between results during the storage period and stabilizer concentration. This result was in agreement with that reported by [31] who found that the whey separation decreased with the addition of Gum Arabic from 5.67 to $1.55 \mathrm{ml}$ in control fermented milk (Robe) and Robe supplemented with $10 \%$ Gum Arabic. The fat content of yoghurt produced by the addition of Gums mixture in concentrate $0.2 \%$ at $0,3,9$ days are $0.96,0.56,0.30$, respectively, and at $0.35 \%$ of the mixture of Gums were 0.91, 0.57, 0.39, respectively and at $0.5 \%$ of the mixture of Gums, concentration were $0.97,0.55,0.33$, respectively There are significant differences between results during the storage period. The protein content of yoghurt produced by the addition of Gums 
mixture in concentrate $0.2 \%$ at $0,3,9$ days in Table 3 are $2.88,2.43,2.09$, respectively, and at $0.35 \%$ of the mixture of Gums were 2.87, 2.30, 2.12 , respectively, and at $0.5 \%$ of the mixture of Gums, concentration were 2.74, 2.35, 1.99, respectively. There are significant differences between results during the storage period.

\subsection{Microbiological (c.f.u/ml) of Yoghurt}

The result of the total count, lactic acid bacteria, coliform, mold and yeast, staphylococci, and salmonella of yoghurt during $0,3,9$ days at different types of the stabilizer are shown in Table 4. Table 4 presented total count bacteria at $0,3,9$ days in yoghurt sample produced by using $0.5 \%$ Gum Arabic $7.5 \times 10^{5}, 9.5 \times 10^{5}, 8.9 \times 10$, respectively. There are significant differences in the total count during the storage period which was increased during storage. The total count bacteria at 0,3,9 days in yoghurt sample produced by adding $0.5 \%$ Guar Gum are $6.5 \times 10^{5}, 9.0 \times 10^{5}, 8.2 \times 10$, respectively. There are significant differences in the total count during the storage period which were an increase during the storage period. Table 4 reported lactic acid bacteria growth at $0,3,9$ days in yoghurt sample produced by using $0.5 \%$ Gum Arabic were $8.4 \times 10^{5}, 1.5 \times 10^{5}, 8.6 \times 10^{6}$, respectively. There are significantly differences in lactic acid bacteria during the storage period. Similar results were found by [32], who found the mean lactic acid bacteria counts of all yoghurts were not significantly different, indicating that yoghurt lactic acid bacteria were not inhibited during fermentation. Coliform bacteria in yoghurt sample produced by using $0.5 \%$ Gum Arabic at 0, 3, 9 days are $2.4 \times 10,1.9 \times 10,1.5 \times 10$ (Table 4 ), respectively. There are significant differences in coliform bacteria during storage. These results are higher than those reported by [25], in which no coliform groups were detected. Whereas no detected coliform bacteria in all yoghurt samples produced by using Guar Gum. The colonies' number of mold and yeast in yoghurt produced by using $0.5 \%$ Gum Arabic as a stabilizer at $0,3,9$ days are $0,0,4.4 \times 10,{ }^{4}$ respectively. There are significant differences in results during the storage period. On the other hand, the growth of mold and yeast in yoghurt produced by using Guar Gum were 0, 0, $7.0 \times 10,{ }^{2}$ respectively. There are significant differences in results during storage period. The mold and yeast showed an increase according to the storage period. These results were higher than that report by [25], which no mold and yeasts were detected. Also,
Table 4 reported the growth of Staphylococcus in yoghurt produced by using $0.5 \%$ Gum Arabic as a stabilizer at $0,3,9$ days are $2.5 \times 10,0,2.5 \times 10,{ }^{2}$ respectively. The growth of staphylococcus in yoghurt produced by using $0.5 \%$ Guar Gum as a stabilizer at $0,3,9$ days are $1.5 \times 10,4 \times 10$, $2.0 \times 10^{3}$, respectively. No Salmonella was detected in any yoghurt samples produced by using two types of stabilizing during the storage period.

\subsection{Sensory Evaluation of Yoghurt Produced by Adding Gum Arabic}

The data in Table 5 gives the average scores of the color of yoghurt produced by using $0.2 \%$ concentration of Gum Arabic at storage period 0, 3,9 days are $4.3,4.2,4$, respectively, and 4.0 , $3.8,3.8$ at stabilizer concentration $0.35 \%$, also showed the color scores 3.9, 3.8, 3.1 at stabilizer concentration $0.5 \%$ at same storage period. These results are similar to those reported by [21], who declared that the color was affected with stabilizer concentration. The Table 5 reported the average scores of the texture of yoghurt produced by using $0.2 \%$ concentration of Gum Arabic at storage period 0, 3, 9 days were $4.2,4.1,3.8$, respectively, and $4.4,4.2,4.1$ at stabilizer concentration $0.35 \%$, also mentioned the texture scores $4.9,4.8,4.7$ at stabilizer concentration $0.5 \%$ at same storage period. There are significant differences in results according to the storage period and stabilizer concentration. The texture became more liquor according to the storage period and coherent according to stabilizer concentration. These results are similar to those reported by [21-25], who found that the texture effect with the addition of Arabic gum and xanthan and carrageenan gums. Also, similar results have been reported by [33], who found that increases in the concentration of stabilizers increase the score of texture. The average scores of flavor of yoghurt produced by using $0.2 \%$ concentration of Gum Arabic at storage period $0,3,9$ days are 3.2, 3.0, 3.5 (Table 5), respectively, and 3.1, 3.1, 3.2 at stabilizer concentration $0.35 \%$, also mentioned the flavor scores 3.2, 2.8, 2.9 at stabilizer concentration $0.5 \%$ at storage period $0,3,9$ days, respectively. There are no significant differences in results according to the storage period and stabilizer concentration. The flavor became more acidic according to the storage period. These results are similar to those reported by [25], who mentioned that no undesirable flavor was detected in any of the treatments by addition xanthan and carrageenan gums. [28] reported 
that the addition of xanthan gum had no adverse effect on the flavor of yoghurt, whereas it did affect texture and body. The table also explains the overall acceptability of yoghurt which produced by using $0.2 \%$ concentration of Gum Arabic at storage period $0,3,9$ days are $3.5,3.6$,
3.6, respectively, and $3.5,3.5,3.5$ at stabilizer concentration $0.35 \%$, also mentioned the texture values $3.6,3.5,3.6$ at stabilizer concentration $0.5 \%$. There are no significant differences between overall acceptability scores.

Table 2. Physicochemical of yoghurt product using Guar gum as a stabilizer (Means)

\begin{tabular}{clllllll}
\hline Stabilizer & $\begin{array}{l}\text { Stabilizer } \\
\text { Concentration } \\
\%\end{array}$ & $\begin{array}{l}\text { Storage } \\
\text { Time } \\
\text { days }\end{array}$ & $\begin{array}{l}\text { Total } \\
\text { Solid } \\
\%\end{array}$ & $\mathbf{p H}$ & $\begin{array}{l}\text { Serum } \\
\text { separation } \\
\text { (m) }\end{array}$ & $\begin{array}{l}\text { Fat } \\
\text { content } \\
\%\end{array}$ & $\begin{array}{l}\text { Protein } \\
\%\end{array}$ \\
\hline GG & 0.2 & 0 & $8.50 \pm 0.05$ & $4.1 \pm 0.60$ & 4.0 & $0.99 \pm 0.30$ & $2.80 \pm 0.20$ \\
& & 3 & $8.08 \pm 0.05$ & $3.9 \pm 0.09$ & 4.1 & $0.51 \pm 0.50$ & $2.48 \pm 0.10$ \\
& & 9 & $7.80 \pm 0.04$ & $3.5 \pm 0.05$ & 4.5 & $0.37 \pm 0.50$ & $2.12 \pm 0.40$ \\
GG & 0.35 & 0 & $8.55 \pm 0.30$ & $3.5 \pm 0.01$ & 2.0 & $0.98 \pm 0.80$ & $2.82 \pm 0.06$ \\
& & 3 & $8.01 \pm 0.20$ & $4.1 \pm 0.07$ & 3.0 & $0.52 \pm 0.06$ & $2.30 \pm 0.02$ \\
& & 9 & $7.88 \pm 0.03$ & $3.9 \pm 0.03$ & 3.0 & $0.31 \pm 0.01$ & $2.19 \pm 0.09$ \\
GG & 0.5 & 0 & $8.61 \pm 0.01$ & $3.6 \pm 0.90$ & 0 & $0.99 \pm 0.09$ & $2.75 \pm 0.50$ \\
& & 3 & $8.10 \pm 0.10$ & $3.4 \pm 0.02$ & 0 & $0.56 \pm 0.01$ & $2.32 \pm 0.80$ \\
& & 9 & $8.01 \pm 0.09$ & $3.2 \pm 0.10$ & 0 & $0.37 \pm 0.09$ & $2.05 \pm 0.90$ \\
\hline
\end{tabular}

GG: Guar Gum

Table 3. Physicochemical of yoghurt product using a mixture of Gum Arabic and Guar gum as a stabilizer (Means)

\begin{tabular}{clllllll}
\hline Stabilizer & $\begin{array}{l}\text { Stabilizer } \\
\text { Concentration } \\
\%\end{array}$ & $\begin{array}{l}\text { Storage } \\
\text { Time } \\
\text { Days }\end{array}$ & $\begin{array}{l}\text { Total } \\
\text { Solid } \\
\%\end{array}$ & $\mathbf{p H}$ & $\begin{array}{l}\text { Serum } \\
\text { separation } \\
(\mathbf{m l})\end{array}$ & $\begin{array}{l}\text { Fat } \\
\text { content } \\
\%\end{array}$ & $\begin{array}{l}\text { Protein } \\
\%\end{array}$ \\
\hline GX & 0.2 & 0 & $8.58 \pm 0.00$ & $4.1 \pm 0.00$ & 3.5 & $0.96 \pm 0.00$ & $2.88 \pm 0.00$ \\
& & 3 & $8.08 \pm 0.00$ & $4.2 \pm 0.00$ & 3.6 & $0.56 \pm 0.00$ & $2.43 \pm 0.00$ \\
GX & 0.35 & 9 & $7.94 \pm 0.00$ & $3.7 \pm 0.00$ & 4.3 & $0.30 \pm 0.00$ & $2.09 \pm 0.00$ \\
& & $8.57 \pm 0.00$ & $4.5 \pm 0.00$ & 5.8 & $0.91 \pm 0.00$ & $2.87 \pm 0.00$ \\
GX & 0.5 & $8.04 \pm 0.00$ & $4.3 \pm 0.00$ & 6.6 & $0.57 \pm 0.00$ & $2.30 \pm 0.00$ \\
& 9 & $7.95 \pm 0.00$ & $4.0 \pm 0.00$ & 6.1 & $0.39 \pm 0.00$ & $2.12 \pm 0.00$ \\
& 0 & $8.61 \pm 0.00$ & $4.2 \pm 0.00$ & 3.5 & $0.97 \pm 0.00$ & $2.74 \pm 0.00$ \\
& 3 & $8.12 \pm 0.00$ & $4.1 \pm 0.00$ & 1.9 & $0.55 \pm 0.00$ & $2.35 \pm 0.00$ \\
& 9 & $7.92 \pm 0.00$ & $4.0 \pm 0.00$ & 3.5 & $0.33 \pm 0.00$ & $1.99 \pm 0.00$ \\
\hline \multicolumn{7}{c}{ GX: Mixture of Gum Arabic and Guar Gum at ratio (1:1) } \\
\end{tabular}

Table 4. Microbiological Characteristics (c.f.u/ml) of yoghurt samples stored for 0,3 and 9 days

\begin{tabular}{lllllll}
\hline Parameter & \multicolumn{6}{c}{ Yoghurt } \\
\cline { 2 - 7 } & \multicolumn{2}{c}{ Zero time } & Day 3 & \multicolumn{2}{c}{ Day 9 } \\
\cline { 2 - 8 } & GA & GG & GA & GG & GA & GG \\
\hline Total count & $7.5 \times 10^{5}$ & $6.5 \times 10^{5}$ & $9.5 \times 10^{5}$ & $9.0 \times 10^{5}$ & $8.9 \times 10^{6}$ & $8.2 \times 10^{6}$ \\
Lactic acid & $8.4 \times 10^{5}$ & $8.5 \times 10^{5}$ & $1.5 \times 10^{6}$ & $2.5 \times 10^{6}$ & $8.6 \times 10^{6}$ & $8.8 \times 10^{6}$ \\
Coliform & 24 & 23 & 19 & 18 & 15 & ND \\
Mold and Yeast & ND & ND & ND & ND & $4.4 \times 10^{4}$ & $7 \times 10^{2}$ \\
Staphylococcus & $2.5 \times 10$ & $1.5 \times 10$ & ND & $4 \times 10$ & $2.5 \times 10^{2}$ & $2.0 \times 10^{3}$ \\
aureus & & ND & ND & ND & ND & ND \\
Salmonella & ND & ND: Yoghurt has Gum Arabic as a stabilizer; GG: Yoghurt has Guar gum as a stabilizer; ND: Not detected
\end{tabular}


Table 5. Sensory evaluation of yoghurt produces by adding Gum Arabic as a stabilizer

\begin{tabular}{|c|c|c|c|c|c|c|}
\hline Stabilizer & $\begin{array}{l}\text { Stabilizer } \\
\text { Concentration \% }\end{array}$ & $\begin{array}{l}\text { Storage Time } \\
\text { Days }\end{array}$ & Color & Texture & Flavor & $\begin{array}{l}\text { Overall } \\
\text { acceptability }\end{array}$ \\
\hline \multirow[t]{3}{*}{ GA } & 0.2 & 0 & 4.3 & 4.2 & 3.2 & 3.5 \\
\hline & & 3 & 4.2 & 4.1 & 3.0 & 3.6 \\
\hline & & 9 & 4.0 & 3.8 & 3.5 & 3.6 \\
\hline \multirow[t]{3}{*}{ GA } & 0.35 & 0 & 4.0 & 4.4 & 3.1 & 3.5 \\
\hline & & 3 & 3.8 & 4.2 & 3.1 & 3.5 \\
\hline & & 9 & 3.8 & 4.1 & 3.2 & 3.5 \\
\hline \multirow[t]{3}{*}{ GA } & 0.5 & 0 & 3.9 & 4.9 & 3.2 & 3.6 \\
\hline & & 3 & 3.8 & 4.8 & 2.8 & 3.5 \\
\hline & & 9 & 3.1 & 4.7 & 2.9 & 3.6 \\
\hline
\end{tabular}

\subsection{Sensory Evaluation of Yoghurt Produced by Adding Guar gum}

The data in Table 6 presented the average scores of the color of yoghurt produced by using $0.2 \%$ concentration of Guar Gum at storage period $0,3,9$ days are $2.0,1.5,1.4$, respectively, and $3.0,2.7,1.2$ at stabilizer concentration $0.35 \%$, also showed the color scores $3.1,3.4,1.5$ at stabilizer concentration $0.5 \%$ at same storage period. There are significant differences in results according to the storage period and stabilizer concentration. These results are near to that reported by [32], who found that the color score was significantly affected by the addition of guar gum. The table as well as reported the average scores of the texture of yoghurt produced by using $0.2 \%$ concentration of Guar Gum at storage period $0,3,9$ days are 1.5, 1.4, 1.2, respectively, and 1.6, 1.5, 1.4 at stabilizer concentration $0.35 \%$, also mentioned the texture values $3.3,3.1,1.3$ at stabilizer concentration $0.5 \%$ at same storage period. There are significant differences in results according to the storage period and stabilizer concentration. The texture became more liquor according to the storage period and coherent according to stabilizer concentration. These results are consistent with the findings of [32], who reported that Guar gum affected the texture of yogurt. The data in Table 6 showed the statistical results of the flavor of yoghurt produced by using $0.2 \%$ concentration of Guar Gum at storage period 0, 3,9 days are $1.8,1.4,1.1$, respectively, and 1.8, $2.5,1.0$ at stabilizer concentration $0.35 \%$, also mentioned the texture scores 2.4, 2.5, 1.0 at stabilizer concentration $0.5 \%$ at storage period $0,3,9$ days, respectively. The addition of Guar Gum did not affect the texture scores. The flavor became more acidic according to the storage period. These results are consistent with finding of [32], who reported that Guar Gum was not significantly influenced by the aroma scores of yogurts. The table also explains the overall acceptability scores of yoghurt which produced by using $0.2 \%$ concentration of Guar Gum at storage period $0,3,9$ days are $1.1,0.8,0.8$, respectively, and 1.1, 1.4, 0.8 at stabilizer concentration $0.35 \%$, also mentioned the overall acceptability scores 1.9, 1.8, 1.6 at stabilizer concentration $0.5 \%$. The addition of Guar Gum did not affect the overall acceptability scores.

\subsection{Sensory Evaluation of Yoghurt Product by Adding Mixer of Gum Arabic and Guar Gum}

Table 7 reported the average scores of the color of yoghurt produced by using $0.2 \%$ concentration of the mixture of Gums at storage period 0, 3, 9 days are 2.7, 2.6, 2.6, respectively, and 1.9, 2.7, 2.7 at stabilizer concentration $0.35 \%$, also showed the color values 3.3, 3.1, 3.0 at stabilizer concentration $0.5 \%$ at same storage period. There are significant differences in results according to the storage period and stabilizer concentration. The data in table showed the average scores of the texture of yoghurt produced by using $0.2 \%$ concentration of the mixture of gums at storage period $0,3,9$ days are 2.5, 2.1, 2.1, respectively, and 2.6, 2.6, 2.0 at stabilizer concentration $0.35 \%$, also mentioned the texture scores 3.2, 3.0, 2.6 at stabilizer concentration $0.5 \%$ at same storage period. There are significant differences in results according to storage period and stabilizer concentration These results are similar to those reported by [25], who mentioned that the texture was affected with the addition of types of gums. The table also mentioned the average scores of the flavor of yoghurt produced by using $0.2 \%$ concentration of Gum mixture at storage period $0,3,9$ days are $2.4,2.8,2.9$, respectively, and $2.5,2.5,2.9$ at stabilizer concentration $0.35 \%$, 
Table 6. Sensory evaluation of yoghurt product containing a Guar gum as a stabilizer

\begin{tabular}{cllllll}
\hline Stabilizer & $\begin{array}{l}\text { Stabilizer } \\
\text { Concentration \% }\end{array}$ & $\begin{array}{l}\text { Storage Time } \\
\text { days }\end{array}$ & Color & Texture & Flavor & $\begin{array}{l}\text { Overall } \\
\text { acceptability }\end{array}$ \\
\hline GG & 0.2 & 0 & 2.0 & 1.5 & 1.8 & 1.1 \\
& & 3 & 1.5 & 1.4 & 1.4 & 0.8 \\
GG & \multirow{2}{*}{0.35} & 9 & 1.4 & 1.2 & 1.1 & 0.8 \\
& & 0 & 3.0 & 1.6 & 1.8 & 1.1 \\
& & 3 & 2.7 & 1.5 & 2.5 & 1.4 \\
GG & 0.5 & 9 & 1.2 & 1.4 & 1.0 & 0.8 \\
& & 0 & 3.1 & 3.3 & 2.4 & 1.9 \\
& & 3 & 3.4 & 3.1 & 2.5 & 1.8 \\
& & 9 & 1.5 & 1.3 & 1.0 & 1.6 \\
\hline
\end{tabular}

GG: Guar Gum

Table 7. Sensory evaluation of yoghurt product containing mixer of Gum Arabic and Guar gum as a stabilizer

\begin{tabular}{|c|c|c|c|c|c|c|}
\hline Stabilizer & $\begin{array}{l}\text { Stabilizer } \\
\text { Concentration \% }\end{array}$ & $\begin{array}{l}\text { Storage Time } \\
\text { days }\end{array}$ & Color & Consistency & Flavor & $\begin{array}{l}\text { Overall } \\
\text { acceptability }\end{array}$ \\
\hline \multirow[t]{3}{*}{ GX } & 0.2 & 0 & 2.7 & 2.5 & 2.4 & 2.5 \\
\hline & & 3 & 2.6 & 2.1 & 2.8 & 2.7 \\
\hline & & 9 & 2.6 & 2.1 & 2.9 & 2.2 \\
\hline \multirow[t]{3}{*}{ GX } & 0.35 & 0 & 1.9 & 2.6 & 2.5 & 2.3 \\
\hline & & 3 & 2.7 & 2.6 & 2.5 & 2.6 \\
\hline & & 9 & 2.7 & 2.0 & 2.9 & 2.5 \\
\hline \multirow[t]{3}{*}{ GX } & 0.5 & 0 & 3.3 & 3.2 & 2.7 & 3.0 \\
\hline & & 3 & 3.1 & 3.0 & 2.5 & 2.8 \\
\hline & & 9 & 3.0 & 2.6 & 2.3 & 2.6 \\
\hline
\end{tabular}

GX: Mixture of Gum Arabic and Guar Gum at ratio (1:1)

also mentioned the texture values $2.7,2.5,2.3$ at stabilizer concentration $0.5 \%$ at same storage period. There are no significant differences in results according to the storage period and stabilizer concentration. The flavor became more acidic according to storage period. These results are consistent with the finding of [25], who reported that the addition of types of gums had no effected on the yogurt flavor. The table also explains the overall acceptability of yoghurt which produced by using $0.2 \%$ concentration of Gum mixture at storage period $0,3,9$ days are $2.5,2.7,2.2$, respectively, and $2.3,2.6,2.5$ at stabilizer concentration $0.35 \%$, also mentioned the texture values $3.0,2.8,2.6$ at stabilizer concentration $0.5 \%$. There are no significant differences between values.

\section{CONCLUSION}

It is concluded that sensory characteristics (texture, color, and overall acceptability) were significantly improved, while the flavor was not affected with type and concentrations of stabilizers, but affected with storage period.
Yoghurt processed with the addition of Gum Arabic had best quality characteristics than yoghurt made with addition Guar gum and a mixture of them. The study recommended doing more researches in rheological, microbial, and sensory characteristics to improve the quality of yoghurt.

\section{DISCLAIMER}

The products used for this research are commonly and predominantly use products in our area of research and country. There is absolutely no conflict of interest between the authors and producers of the products because we do not intend to use these products as an avenue for any litigation but for the advancement of knowledge. Also, the research was not funded by the producing company rather it was funded by personal efforts of the authors.

\section{COMPETING INTERESTS}

Authors have declared that no competing interests exist. 


\section{REFERENCES}

1. Seo MH, Lee SY, Chang YH, Kwak HS. Physicochemical, microbial, and sensory properties of yogurt supplemented with nano powder chitosan during storage. Journal of Dairy Science. 2009;92.

2. Zare F, Boye JI, Orsat V, Champagne C, Simpson BK. Microbial, physical and sensory properties of yogurt supplemented with lentil flour. Food Research International. 2011;44:2482-2488.

3. Ramesh P, Vengala RY, Shaik A, Sharma M. Fermented milk in protection against inflammatory mechanisms in obesity, a book chapter in: Immunity and inflammation in health and disease. Academic Press; 2018.

4. Behare VV, Gundale SS, Deshpande AV. Study of electrical conductivity of Li2OB2O3-SiO2-Li2SO4 glasses and glassceramics. Solid State Ionics. 2016;298: 57-62.

5. Lee WJ, Lucey JA. Formation and Physical Properties of Yoghurt. Asian. Aust. J. ANIM SC. 2010;23(9):1127 -1136.

6. Hansen PMT. Food hydrocolloids in the dairy industry. In K. Nishinari, E. Doi (Eds). Food hydrocolloids: structures, properties and functions. New York: Plenum Press. 1993;211-224.

7. Slavin, Greenberg. Arabic gum is used for its nutritional and surface properties; 2003.

8. Sulieman AE. Gum Arabic as thickener and stabilizing agents in dairy products in: Gum Arabic structure, properties, application and economics. Elsevier Academic Press; 2018.

9. Rosell CM, Rojas JA, Bendito de barber C. Influence of hydrocolloids on dough and bread quality. Food Hydrocolloids. 2001; 15:75-81.

10. Soukoulis C, Panagiotidis P, Koureli R, Tzia C. Industrial yogurt manufacture: monitoring of fermentation process and improvement of final product quality. Journal of Dairy Science. 2007;90:26412654.

11. Soukoulis Costas M, Stefan Linden, Martin Wegener. Negative refractive index at optical wavelengths. Science. 2007; 315(5808):47-49.

12. Rezaei $R$, Khomeiri $M$, Kashaninejad $M$, Aalami M. Effects of guar gum and Arabic gum on the physicochemical, sensory and flow behavior characteristics of frozen yoghurt. International Journal of Dairy Technology. 2011;64:563-568.

13. Sekhavatizadeh S, Sadeghzadehfar S. The effect of guar gum as the fat substitute on some sensory and chemical properties of low-fat yogurt. Journal of Innovation in Food Science and Technology. 2013;5:29$38,129$.

14. Kosikowiski FV. Cheese and fermented milk products. $2^{\text {nd }}$ Ed., F.V. Kosikowiski and Associates Brooktondale N.Y; 1982.

15. AOAC. Official Methods of Analysis. AOAC international, 17th ed., Gaithersburg, MD, USA, Official methods. 120.124, 926.08, 955.30 2001.14; 2003.

16. AOAC. Official Methods of Analysis. Helrichik, (ed.) 15th edition Association of Analytical Chemists, Inc. USA. 2000;777.

17. Morton, John, Uta Frith. What lesson for dyslexia from Down's syndrome? Comments on Cossu, Rossini, and Marshall; 1993.

18. Thatcher FS, Clark DS. Microorganisms in foods: Their significance and methods of enumeration. University of Toronto. Press, Baffalo NY; 1968.

19. Rayman KN, Malik, Jarvis G. Performants of four selective media for enumeration of staphylococcus aureus in corned beef and in cheese. J. Food Prot. 1988;51:878-888.

20. Khosrowshahi Sara 1, Mohammad Ali Hesarinejad. The effect of Prunus cerasus gum exudates addition on physic-chemical, rheological and sensory properties of yogurt. Annual Transactions of the Nordic Rheology Society. 2017;25:41-45.

21. Kocabas, Muhammed, Salih Karagoz, Emre Akbas. Self-supervised learning of $3 d$ human pose using multi-view geometry. Proceedings of the IEEE Conference on Computer Vision and Pattern Recognition; 2019.

22. Huyam E. Hamad, Abdel Moneim E. Sulieman, Zakaria A. Salih. Quality Aspects of the Sudanese Fermented Milk (Robe) Supplemented with Gum Arabic powder. Discourse Journal of Agriculture and Food Sciences. 2013;1(1):8-7.

23. Jung $E H$, Jeon $N J$, Park EY, Moon CS, Shin TJ, Yang TY, Seo J. Efficient, stable and scalable perovskite solar cells using poly (3-hexylthiophene). Nature. 2019; 567(7749):511-515.

24. Ishizuka, Andrew $S$, et al. Protection against malaria at 1 year and immune correlates following PfSPZ vaccination. Nature Medicine. 2016;22(6):614-623. 
25. Nima Ali Al, Trevor Archer, Danilo Garcia. The happiness-increasing strategies scales and well-being in a sample of Swedish adolescents. International Journal of Happiness and Development. 2013;1(2): 196-211.

26. Abd El-Salam M, El-Etriby $\mathrm{H}$, Shahein $\mathrm{N}$. Influence of some stabilizers on some chemical and physical properties of yoghurt. Egyptian Journal of Diary Science. 1996;24:25-36.

27. Harwalkar V, Kalab M. Relationship between microstructure and susceptibility to syneresis in yogurt made from reconstituted nonfat dry milk. Food Microstructure. 1986;5(2):287-294.

28. El-Sayed, Mohamed, et al. Transport mechanism (s) of poly (amidoamine) dendrimers across Caco-2 cell monolayers. International journal of pharmaceutics. 2003;265(1-2):151-157.

29. Mckanna AB. Effect of homogenization pressure and stabilizer conc. On the physical stability of long-life laban - New
Zealand J. of Dairy Sci. and Technology. 1987;22:167-174.

30. Abd Alla MOM. Effect of processing conditions on the on the microbial quality of white pickled cheese. Ph.D. Dissertation, University of Tennessee, Knoxville, USA; 1992.

31. Hamad, Yousif M., et al. Molten carbonate fuel cell combined heat, hydrogen and power system: feedstock analysis. Energy. 2013;6.2:31-35.

32. Youngseung Lee, Yoon Hyuk Chang. Influence of guar gum addition on physicochemical, microbial, rheological and sensory properties of stirred yoghurt. International Journal of Dairy Technology. 2016;69(3):356-363.

33. Moeenfard M, Mazaheri Tehrani M. Effect of some stabilizers on the physicochemical and sensory properties of ice cream type frozen yoghurt. American-Eurasian Journal of Agriculture \& Environment Science. 2008;4:584-589.

(c) 2020 Salih et al.; This is an Open Access article distributed under the terms of the Creative Commons Attribution License (http://creativecommons.org/licenses/by/4.0), which permits unrestricted use, distribution, and reproduction in any medium, provided the original work is properly cited.

Peer-review history:

The peer review history for this paper can be accessed here: http://www.sdiarticle4.com/review-history/62151 